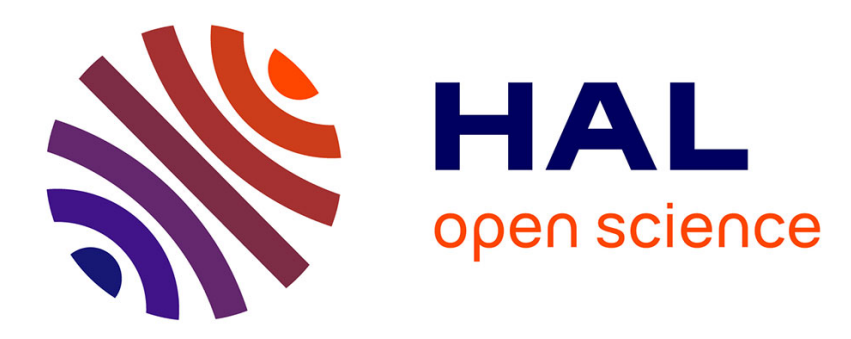

\title{
Intimate Politics: The Art of the Political Relationship in Lebanon
}

\author{
Isabelle Rivoal
}

\section{To cite this version:}

Isabelle Rivoal. Intimate Politics: The Art of the Political Relationship in Lebanon. Anthropology of the Middle East, 2014, 9, pp.1 - 17. 10.3167/ame.2014.090102 . hal-01421176

\section{HAL Id: hal-01421176 https://hal.science/hal-01421176}

Submitted on 28 Dec 2016

HAL is a multi-disciplinary open access archive for the deposit and dissemination of scientific research documents, whether they are published or not. The documents may come from teaching and research institutions in France or abroad, or from public or private research centers.
L'archive ouverte pluridisciplinaire HAL, est destinée au dépôt et à la diffusion de documents scientifiques de niveau recherche, publiés ou non, émanant des établissements d'enseignement et de recherche français ou étrangers, des laboratoires publics ou privés. 
Quoting as: Isabelle Rivoal (2014) «Intimate Politics. The art of the political relationship in Lebanon ", Anthropology of the Middle East, vol.9, n'1, spring 2014, p.1-17.

\title{
Intimate Politics:
}

\section{The Art of the Political Relationship in Lebanon}

Isabelle Rivoal (CNRS) ${ }^{1}$

\begin{abstract}
This paper aims at analysing patron-client relationship out of a detailed ethnography of the everyday life of Walid Junblat's followers in Lebanon. It reveals how intimate people are with political figures, talking to them (in the forms of their pictures), talking about them, thinking through them, playing off this intimacy to enter the political competition, etc. Patrons also need to play their part in the relation. The weekly political gatherings held at Junblat's palace are the momentum of this aesthetic of power. The detailed observations of the tempo the lord impulses to the ritual audience add complexity and fluidity to the relation.
\end{abstract}

Keywords: Patronage, domination, aesthetic of politics, martyrdom, Lebanon, Junblat.

\section{Biographical note}

Dr. Isabelle Rivoal is a social anthropologist. She holds a senior researcher position at the French National Center for Scientific Research (CNRS). She is a member of the Laboratoire d'Ethnologie et de Sociologie Comparative (LESC). She is also Scientific Deputy Director of the Maison Archéologie \& Ethnologie. Most of her research program is dedicated to exploring the relationships between local communities, communal organizations and the state in NearEastern societies. She has conducted long-term fieldwork in Druze settlements in Israel and Lebanon.

1 I particularly thank Maryline Bocquet-Le Quéré and Erin Taylor for their invaluable help with the English version of the text. 
The protracted confrontation that has been plaguing Syria for two years has revived the familiar schema of oriental tyranny, comprehended as absolute control of power and resources enforced on the society through forms of threat and violence. For decades, studies of domination and violence in the Arab world have viewed them through the schema of asymmetrical personal relations, which foster visible practice of power and ostentatious challenges. While patronclients relationships have received attention in anthropological literature, relatively little work has considered the centrality of intimacy in building these kinds of personal relationships. The term "relations" in patron-client relations has long been taken as a structural link that aims to characterise one typical form of social relation. Patron-client relation refers to forms of asymmetrical exchange (protection versus support or jobs versus the vote, for example) and is fuelled with personal marks of power and allegiance.

It is crucial to theorize the notion of relations as being more than a mere structural or formal link between individuals or social groups in such a way as to go beyond the now familiar asymmetrical characterisation of patron-client relationships. An ethnographic approach examining how relations are actually invested and experienced in the everyday life may help to carry the issue in a new direction. Nothing is ever fixed in such a relational society. The patron and the client keep on constantly acting out the relation, lest it loses its consistency. Based on a careful attention to ethnographic details, my description of the multifaceted ways that political patrons and followers relate to each other in Lebanon may provide analytical potential for the anthropological understanding of communal attachment and identity in the Middle East.

\section{Approaches to Political Patronage and Domination in Lebanon}

Analysis of Lebanese politics has mainly been based on the study of patronage relations and the forms of domination that organize them. More precisely, it has focused on understanding the ambiguous relationship between political leaders, the "zaîm-s" likely to be elected to parliament (Gubster 1973) and their henchmen, the "'abadây-s. This is a relationship that facilitates the control of communitarian and partisan masses. If this relationship has been privileged as a manifestation of power, it is because of the uniqueness of Lebanon, which can be described as a non-Hobbesian society in the sense that the state and civil society are not distinct. The State in Lebanon is no more than a patronage system (Gilsenan 1977) which according to Michael Hudson's well-known phrase

makes it a "Precarious Republic" (Hudson 1968). It is the constant reality of the 
communities, reflected in Lebanon's legal foundations and impeding the emergence of a central government (legitimised by a civil society), that explains the predominance of patronage as the encompassing political organisation. Most Lebanese political sociologists have endeavoured to account for the articulation of local realities (the scale of local partisan societies) and national realities (the government institutions in Beirut) in terms of social control founded on violence. Mediation between these two spheres plays a pivotal role in maintaining the confessional system.

What is the link between a political leader and those who claim to support him? How are partisan loyalties formed and perpetuated? What are the manifestations in daily life of a political relationship that is characterized by its personal dimension? And above all, how can one possibly account for this personal dimension in a political organization renowned for being founded on coercion and violence? Michael Gilsenan is certainly the scholar who has best understood that domination is not a mere dimension of political patronage; rather it is a social practice and an art with a dedicated aesthetic. In northern Lebanon, hierarchical status is presented as perfectly natural and this particular feature is more significant than the meaning that people attach to it. Domination is above all considered as a factual state (thingness). But this does not signify that it remains implicit. Rather it has to be displayed, exhibited, and performed so as to reach its essence and become the matrix of local history through the narration of the leaders' great acts (Gilsenan 1986, 1989). Domination is thus constantly reproduced and replayed in its most arbitrary forms in the most varied social situations, according to aesthetics of violence which confers upon the lord an iconic dimension while their henchmen ('abadây) are in charge of organizing and perpetuating "the worldly order" (Gilsenan 1996: 3-22).

Deep economic changes (Dib 2004: $91 \mathrm{sq}$ ) and years of civil war have almost ruined the political order founded on land ownership (for agricultural use). They have probably also altered the ways that people perceive the 'abadây, consequently changing the relationship between the zaîm and his followers, particularly in rural areas. The expansion and the development of Lebanese patronage networks came to a halt in 1975 following the collapse of the State, towards which the whole system of political relations is geared. More precisely, the State in its institutional form continued to exist but was no longer the privileged place for the expression of power struggles. Rather, these came to be measured in the context of militia clashes. The most important consequence of this collapse has been the strengthening of the various networks of supporters at a more local level. The political leaders have nearly all become influential figures in urban areas working in trade and finance. Most henchmen are now expected to have the skills of administrators, and the old "aesthetics of honour" has been democratised and can be claimed by any citizen (Johnson 2001: 40-47). The 
community dimension is consequently the most relevant element in explaining how political leaders have been able to maintain their legitimacy in spite of the coercive and unfair nature of their domination (Khalaf 2001: 42-45; Kingston 2001). How, then, can people remain so loyal and respectful of the community spirit? It cannot be solely the result of domination, and these leaders cannot possibly have ceased to represent the local societies that guarantee their dominance.

Political power in Lebanon plays a role that goes beyond the mere control and representation of people. The Lebanese civil existence rests on communal belonging: individuals are born, marry, and die in the community. Hence, civility is essentially forms of political action outside communal politics. It has an existence of its own, but it remains a political residual fact that does not reveal the various aspects of the social contract in the Lebanese context (Picard 1994; Karam 2006). Nor does it give any clues to help us to understand the durability of patronage relations. Power is to be considered a principle of social organisation, a laboratory to develop ideologies and common memories.

Why not consider it as a sort of work of art? It organizes people's daily life as well as political life, since every single ordinary aspect of life within communities is necessarily endowed with a political character. It is therefore important to define this particular "political character". In this context, the leader is more than a mediator between local politics (the communities) and national politics; he does more than represent a 'asabiyya or traditional loyalties. His authority works as a reference and this authority is shaped by the relationship that links the leader to his followers. Rather for all parties, politics is predicated upon achieving an ideal level of intimacy between the community and its leaders, some of which is directly experienced and some of which is mediated.

\section{Framing the Lord: The Presence of the Leader in the Follower's Intimate Spaces}

In Lebanon, some politicians are referred to as "poles" (aqtâb) because they polarise regional and community clients. Walid Junblat is one of these politicians. The leadership he exercises reflects the evolution of a peasant society ruled by landowners towards a middle class of migrant workers who are constitutive of local polity. That this relationship has persisted for hundreds of years is further emphasised by the fact that Walid Junblat belongs to a longestablished lineage of leaders. The Junblats settled in the Shuf Mountains at the beginning of the $17^{\text {th }}$ after forming an alliance with Emir Fakhr al-Dîn II al-Maanî 
(Hichi 1973: $56 s q$ ) and became one of the leading families in the area after the 1711 clashes $^{2}$.

It is well known that the Junblats succeeded in adapting to the modalities of the new political and economic framework of independent Lebanon. In the years following his first election as a deputy, Kamal Junblat redistributed the lands belonging to his family, anxious to respect the socialist ideal. He created the PSP (Parti Socialiste Progressiste) in 1949. The partisan structure gave birth to the militia and to the creation of a genuine territorial administration from 1983 to 1990 (Harik 1993; Rivoal 2001). Junblat also made various economic investments during and after the war, and started to monitor the financial assets granted to the Ministry of the Displaced and Reconciliation ${ }^{3}$.

Walid Junblat therefore seems to be a perfect example of a Lebanese political boss who is established in Beirut, yet depends on regional voters. As the heir of a political lineage that is well-known in Lebanon, he has endeavoured rather successfully to play a part on the international scene, expanding beyond his traditional patronage network despite the dismantling of the partisan stately structure founded during the 1980s. He has been blamed for his role as a war chief during the years of the conflict and mocked for his shifting political alliances, and he has been harshly criticised for provocative speech and behaviour, but he has nonetheless managed to become a leading figure in Lebanese political life. If he wished, he could certainly be a distant lord, utterly consumed in the mysterious workings of national policy. If this were the case, his partisan structure or henchmen would be delegated responsibility for ensuring the loyalty of local clients. If patronage relations were indeed nothing more than a business of mutual exchange of services and recommendations, and if it was founded only on the practise of coercion, the political leader would cease to be a relevant reference, since the relationship would cease to be necessary.

This is, at least, what I had long supposed before I decided to extend my enquiry in Sydney, where I worked with migrants from the Lebanese Druze community. As they had made their own way out of the local political sphere where Walid Junblat is an acknowledged central political reference, these migrants had a social position that was no longer determined or influenced by patronage relations or the confessional system. I wanted to observe this so as to be able to compare the narratives of Junblat's leadership in both places. In Sydney, I met Nabil at a meeting organised by the Sydney Union of the Druzes. Soon after, this affluent man, who had succeeded in founding a small local

2 When the muqâta'ajî system was abolished in 1841, the Junblat clan was ruling over 200 villages and 30,000 people (Khuri 2004: 140).

3 The Ministry for Displaced People was created on July 7, 1992, by decree of the Minister Council. It was given a special fund to assist with reconstruction and assist the return of displaced people to their homes. Walid Junblat was Minister for Displaced People from 1992 to 1998. 
company, invited me for lunch with his family. Nabil had been living for more than thirty years in Manly, a rather wealthy suburb in Northern Sydney. His will to settle far from the Lebanese community of Sydney reveals his paradigmatic ambition to go his own independent way.

Nonetheless, as soon as my host let me into his house and invited me to sit down in his living room to have a cold drink, as is usually done, I felt as if I had crossed a threshold and left behind boisterous Sydney to find myself all of a sudden back in the Shuf Mountains. I started taking in the surroundings. There was something familiar about everything, and it had nothing to do with the scarce furniture or the smells of coffee and spiced roasts coming from the kitchen. Rather, this feeling arose from the framed photographs on the walls and the chest of drawers. There was a picture of the most venerated Druze religious man right next to a portrait representing Kamal Junblat. There was a portrait, to which my host drew my attention, of the whole family standing around Walid Junblat. Undoubtedly, these pictures were conveying a sense of deep familiarity. I had never so accurately realised their centrality to my sense of the Shuf.

Within the context of his study on the migratory experience, Ghassan Hage (1997) contrasts the notion of feeling "at home", which he refers to as "homebuilding", with the mere fact of building a house, "house-building". An affective dimension is attached to "home-building", meaning the building of a place where the family are perfectly comfortable and can feel secure in the sense that one is not submitted to the arbitrary nature of official law. It is also a place where the notion of community can be experienced on a daily basis, through the sharing of symbols, references, values, and moral standards that allow the family to communicate freely, far from external reality. Feeling "at home" is actually an intimate experience that requires a strategy to set up a private life in order to be with one's family in a place of one's own, on an independent basis. The "ahlân wa sahlân" greeting me at his threshold, and the flavour of the tabbuleh (the traditional salad) I was offered gave rise to the strange feeling that I had been transported into Lebanon. But the sensation mostly arose from the familiar "presence" of Walid bey and Kamal bey (the Druze chiefs) who were right before my eyes. Coming into his home from an obviously Australian exterior world, the familiar presence of the Junblats in the intimacy of home triggered my own interiorised version of Lebanon ${ }^{4}$. During my frequent visits to the Shuf, I had become accustomed to seeing these portraits on the walls and infer meanings from their layout. I considered them to be conventional signs of allegiance to the regional leader.

The most frequent mise-en-scène seen in the homes I visited in Lebanon is the display of a black and white portrait of Kamal Junblat surrounded by portraits of

4 One version of Lebanon of course, one amongst many others depending on the political and religious iconography displayed. 
the head of the household and his late father. They are placed in a triangular arrangement in which Kamal Junblat visually dominates the scene. The presence of Kamal Junblat's portrait is a sign of the family's support of the Junblati faction at large, whereas a portrait of Walid Junblat is much more significant with regard to the family's allegiance to the political leader. Where these pictures are absent, they testify to a distrust regarding Junblat.

With some experience, the visitor can perceive from the portraits exhibited in the Lebanese lounges the nature of the bond that links the leader to his followers. For a long time, my understanding of the iconography rested upon a cultural deciphering of politics and patronage relations. However, I later realised that my assumption that the portraits are a way to signal allegiance missed a great deal of meaning. Certainly, every man uses his lounge room to exhibit his political ideas to the visitors he receives there. The layout of the room, the decoration, the frames hanging on the wall or standing on the furniture, everything concurs to show his guests who their host is and what his allegiances are.

At Nabil's house in Sydney, Walid Junblat does not only stand in the reception room as a reminder of the political allegiances of the family back in Lebanon. His portrait holds the most important place at the centre of the family's daily life. Right next to the kitchen table there is a bench with family photos in frames placed upon it. The central frame displays a picture of Walid Junblat with Nabil, his wife and their children that was taken when they last visited Mukhtara. This picture seems as though it were reiterated, since the portrait stands among other family clichés of their son graduating, their engaged daughter, and younger children and nephews. Normally, guests are not invited into the kitchen, and so these photos were not placed there for display purposes; it has nothing to do with a conventional sign of allegiance as might have been the case in the Shuf, for instance. In the context of migration, it takes its full meaning in the creation of intimacy: the picture says something for you and it belongs to you. The role of the leader goes beyond the patron-client relation: he is a whole member of the family.

Beyond the case of Nabil, it is not surprising to observe that the lounge room, which represents the masculine space par excellence in Lebanon, is not the only place where the "presence" of political leaders is felt. Indeed, they are often found in the kitchens in the form of small portraits on fridges, where they sit beside portraits of pop stars or movie actors. Sometimes they appear more unexpectedly in places where they only seem to be keeping company to the family. During my sojourn in the Shuf, I used to visit a woman whom I knew well enough to be invited to carry on a conversation in the tiny room where she was frying potatoes. Above the big pot full of boiling oil, a newspaper clip showing Taymur's smiling face (Taymur is Walid Junblat's eldest son) was fixed to the 
wall. On one occasion, he woman suddenly interrupted our conversation to gaze on the portrait. While wiping it with the towel she was holding in her hand, she said with affection: 'Oh! Look at what I'm doing to the poor young man; he is all covered in oil now!'

These portraits are not mere ornaments in the house; they play an active part in the sense that they facilitate a relationship between the leader and the family on a daily basis. They serve as substitutes for the leader in flesh and bone, thus making it possible to experience a familiar relation (based on affection) with the leader. The woman's fond gestures spoke for themselves, as she was wiping the newspaper cutting, going right and left in circular movements: she was actually wiping a real face. Such gestures are revealing of how political leaders do not solely represent authority: they also live by side with their people. The scene reminded me of the way that old women behave when they come across Walid Junblat at a meeting in the village or at Mukhtara. They make him bend forward so as to kiss his forehead and wish him a long life. But the feeling of affection they express when they meet him in real life is quite different from the feelings experienced in front of the picture: there is indeed some deference and even a submission to authority in real life, as the women bless him 'May God give you long life, and may he keep you above our heads, Walid Bey'.

Nonetheless, this feeling of affection and intimacy is not only to be expressed in the symbolic mother-son relationship. I can remember one particular morning when I was sipping my coffee in the family I usually stay with when in the Shuf. Marwan, the younger son of the family, had just started university and had made acquaintances among the members of the PSP youth. He had returned home

with a calendar and had mounted it right in the middle of the kitchen wall, facing the sofa. After he had greeted us, his eyes still heavy with sleep, he exclaimed, gazing at the Druze leader portrait on the February page: 'Hello ya Walid Bey, what a splendid day today!'

In these two scenes, the image is not just exhibited to show exactly where one stands in the hierarchy of personal relationships that make up the political sphere. In the kitchens and the rooms next to them, which represent cosy and womanly places, the portraits that are displayed in all simplicity - with no frame around them - make it possible to express affection towards the leader. This is not the case with the perfectly-framed portraits in lounge rooms.

\section{Feeling at Home in the Shuf Mountains}

The creation of this intimacy does not arise solely from images, which are a substitutes for the leader to whom one can speak in an informal way. People are also influenced on a daily basis and in various ways by his speech. Ibtissam 
cannot be said to have a close political link with the Junblats. Her husband has two patrilateral cousins who have made a fortune in the banking sector and who consequently suffered from Walid Junblat's violence during the war because they refused to contribute to the financing of the militia. One had been abducted, leaving open contentious issues between her husband's clan and the lord of the place. Being a loyal member of her husband's family prevented her children from mixing with the PSP youth, and she was not authorised to go to Mukhtara Palace to ask the bey for any favours. However, she comes from a family that is politically close to the Junblats, and she remarked: 'Walid Bey knows I love him and he knows my situation; I'm sure he knows why I don't go to Mukhtara. I first and foremost think about my children's future.' However, she derives strength from Kamal Junblat's teachings.

'Every morning, I get up at six and I start the day by reading a text of almu'allim ("the professor," as Kamal Junblat is known among his followers), and then I practise yoga. After this ritual, I feel more relaxed to face the day to come. I would be too nervous otherwise. Kamal bey showed us the way.'

Kamal Junblat is the one figure who inspires people this way. This is due to the fact that his stature is based on religious symbolism. This stature was amplified by his violent death, which rendered him a martyr. In this particular case, the political representative of a community has become a spiritual guide whose texts have been read and reread, and even integrated into the practice of yoga. In this regard, Kamal's Junblat's writings are used in a way that is reminiscent of the injunction to the Druze religious community that they should read the sacred Scriptures in such a way that they incorporate the book into their lives, to the point of becoming the book (Rivoal 2000). The way that Ibtissam "practices" Kamal Junblat's spiritual teachings along with yoga seems to approximate a spiritual asceticism that eases her daily life.

Kamal Junblat's speech, which is also found in writing, can be assimilated into daily life in this fashion. But there are indeed other ways to share a sort of private moment with the political leader. Consider, for example, the audio recordings of political leaders' speeches and the musical montages that are popular among the young generation. The leader's spoken word is mixed, set to music, and then sold in small shops in the form of CDs, thus being assimilated by the young once they have completed the musical editing. Favourite passages are selected and become hits. Marwan would rather listen to Georges Wassuf and Rami Ayash when driving, but it is the remixed passages of Walid Junblat's speeches that he plays constantly on his laptop while studying for his exams.

The presence of the leader in a geographical space where he and everyone feel "at home" also generates a feeling of intimacy. As someone once told me: 
'When Walid Junblat drives up to the Shuf for the weekend, he never uses his official deputy's or minister's car. You see, everybody knows his registered $270004 \times 4$ wheel vehicle round here. I can remember when Walid Bey went to pick up his son who stayed with Patrick Perez at the French cultural centre at Dayr el-Qamar. He would arrive with his jacket on his shoulder.'

Quite differently from what Michael Gilsenan (1996) had observed, the "lord" does not act as a distant figure who wishes to dominate his followers entirely. On the contrary, he is willing to present himself as a casual man, liberated from urban dress codes and political bondage. We can observe here a kind of enlarged mirror reflecting of the leader's place in the intimacy of home: as soon as he enters the Shuf, Junblat is "at home". In this context, home implies the possibility of a place where you are not subjected to the law. Ghassan Hage (1997) considers this quality to be the most important as far as the notion of "home" is concerned. The reference to "home" must be considered as a social space where political challenge has no place at all.

The concept of "patriarchal connectivity" proposed by Suad Joseph (1993, 2005) in her writings on the construction of family relationships in Lebanon demonstrates the ambivalent nature of this hierarchical space. By "connectivity," Suad Joseph refers to a fundamental quality that one must have in order to be considered a full human being in Middle Eastern societies. It implies that the person never thinks of his own self in an independent way, but only in relation to significant others. In other words, the maturity of a human being is judged on his capacity to meet the wishes of his close relations, and on a wider scale, all the persons likely to become acquaintances, anticipating their needs and speaking on their behalf, taking into account what they like and what they do not. In this context, prominent males place social relationships at the very heart of what they do. This means that they can gain social importance and recognition only if a large number of people are ready to grant their wishes. The political leader and his followers exemplify this web of intermingling relations perfectly.

These references to Walid Junblat as a casual man "at home" in the Shuf emphasise his role as the "symbolic" family head. We can thus understand the importance he is given in the intimacy of people: he shares their daily life in the sense that he is an extension of them and they consider that they are an extension of him. He is undoubtedly an important figure who participates in social dynamics at a local level, and this contribution has a great influence on what the leader and his followers expect from one another. 


\section{The Leader's Changing Mood, or the Lebanese Art of Politics}

The personality of each individual likely to become an element of the community is built on narrative elaboration within the group. Anecdotes concerning what one likes, one's way of being and acting, are regularly mentioned and related within the family sphere and also whenever people come to visit. This is how one becomes an element of the relational matrix. It is not surprising, then, that people enjoy talking about Walid Junblat's character and personality. They even expect him to provide them with clues regarding his personality so that they can make up their own stories. Indeed, it's important for the leader to forge a style which makes him unique: a very personal style is the outward sign that brings credibility to the existence of an abundant biography. A leader who has his own style is a source of inspiration for people to create their stories. As far as Walid Bey's intimacy is concerned, women know what his favourite dishes are. Young people find very exciting to watch a particular video on youtube that shows the "president" sipping his mate, the Argentinian herbal tea Druzes are very fond of, which he prefers bitter. One person commented to me:

'Walid Junblat is keen on taking photos and driving his motorbike, he also enjoys having a nice walk alone in the Shuf, with no bodyguards around. He actually always drives his car himself and Marwan Hamadeh [is closest political companion, also a Minister] is on the seat beside him. Unlike his father, he's not fond of writing and reading books, but he's clever and cunning.'

People like to talk to the visitor in the Shuf about what the leader enjoys, about his habits, his personality. "Teaching" these details to someone is an important part of initiating them into the knowledge that the group shares. But when families hold conversations in the evening (sahra-s), they seem to be more interested in what Walid Bey might think about such or such an issue, according to what they know about him, his choices, and his personality. This habit of placing Walid Junblat at the centre of conversations is quite frequent among young people who consider him as a sort of maternal uncle affectionately involved in their life choices. Walid Junblat is an important reference in daily life. But this reference is not only a personal reference. It also challenges the relationship that people have with each other.

Debating politics in Lebanon generally involves analysing the intentions of the various protagonists in a given situation. Intentions are often more revealing than practical actions or words and are more likely to be subject to conjecture. Debates bring about the opportunity for a "game" between those who elaborate an analysis and those for whom the analysis is intended. The whole art of the game is to produce evidence, thus casting light on this particular relationship and 
at the same time pointing to the various signs and clues likely to unveil the political intentions of the narrative's protagonist. This unique approach finds an echo in the conversation I had with the leader of the Sydney PSP wing. Being far from Lebanon, Doctor Mamduh said that he had to spend many hours every day reading Lebanese, Syrian, and Saudi newspapers, insisting on the importance of being good at reading between the lines. He said to me:

'This morning, for instance, [April, $1^{\text {st }} 2008$ ], the Nahar newspaper only said in a small article that Walid Bey had been seen on his way to the airport with his car window wound down. Look, this is a very significant sign because it shows that he feels relaxed. And I can tell you that he really is at present because the Arab League summit is holding in Damascus these days, which means that his safety is guaranteed.'

Doctor Mamduh explained to me, 'even when you are good at reading signs, politics remains difficult to come to terms with if you live far away. This is the reason why I regularly call the deputies Wael Abu Fa'ur and Ghazi al-'Aridi.'

'I call Ghazi more often because we come from the same region. But it's not easy to get real information from them. So the best thing to do so as to keep in touch is call the old friends (rifâq) on the phone. They are on the spot, they talk and say what's going on. And of course I regularly call people at Mukhtara. There's always a young man who answers and gives news. So we know whether Walid Bey is upset or obliged to do something he doesn't want to do, or on the contrary if he's in a good mood. We can keep in touch that way.'

During the public hearings that Walid Junblat holds every Saturday morning, his Mukhtara residence transforms to a theatre stage in which his followers expresses and play out the personal link (which characterises the relation of patronage) that they have with the leader. It is the privileged place where one can ask a favour to get a job, or financial support in case of a hospitalization. There, followers are allowed to raise specific concerns, request mediation, or bring a personal invitation to the wedding of a son. On this political stage that is the oriental diwân, the leader acts both as a conductor and as a host. These public hearings are never held in a formal way. Walid Junblat sits on a plastic chair turning his back on the balcony, his visitors facing him on the sofas running along the high walls of his sitting-room. According to the type of visitors coming forward in turn, he may talk in a low voice or on the contrary show his irritation concerning a request annoying him: 'I'm wasting my time and my coffee listening to your stories!' Alternatively, he may stand up all of a sudden and show compassion to a visitor, to whom he directly gives a banknote out of his personal purse. He then takes the invitation card handed to him, all the while looking in 
another direction: 'Well, who is next? Come on!' He then goes back to his seat, lost in thoughts for a time before standing up again to accept, with a smile, a kiss on his forehead from an old woman who wishes him a long life. And immediately after that, he claims that he has enough of people always wishing him a long life and that he would like to be left alone. His mood seems to always be changing. He may accept people's gratefulness at some point, and at other times he can be yelling at someone setting a coffee table before him so that he can put his agenda on it. 'Hey, these tables are coffee tables!' Then he stands up, sits down again, stays a short while on the balcony, has a small aside with his "administrators", then vanishes into another room just to come back some time later, thus making a visiting delegation wait for him.

In this context, the diwân is not merely a place where one can express oneself and witness the statutory hierarchy ranking that is commonly described by literature. It is also a stage where the obvious tension between the leader and those who visit him is played out. This tension is in keeping with the "mood of the leader", who is very keen to keep the rhythm of these public hearings changing constantly. It appears as if it is really important for him to remain unpredictable before an audience for whom political skills partly consist of finding the way to understand his actions and render him predictable. All of this is part of Walid Junblat's style. The bey does not adopt a hieratic attitude in his own lounge room, which would say: 'look at me!' Observing the arrangement of the family portraits that adorn the walls of the different lounge rooms of his residence, walking in the refined garden spread out along the palace terraces, admiring the gazelles, enjoying the sweet-smelling flowers and waterfalls that he permits the visitors he has selected to visit as "tourists", all of these aspects allow a more intimate approach towards the leader.

When he receives visitors in his lounge, Walid Junblat notably differs from the figure on the portrait in people's homes. He is not just a reference; rather, he takes decisions and gives the impressive performance expected from the lord of Mukhtara. His actions are meant to express the various forms of relationships that clients have with him. He is not an iconic reference showing who he really is, predictable and never changing. Rather, he has to meet people's expectations without locking himself into a particular relationship with them, but the people are perfectly aware that he would not be such an important local figure without these weekly public hearings, as revealed in a comment from a critic: 'If one day people stopped going up to Mukhtara, I'm sure the bey would commit suicide.'

Political closeness to the leader is not therefore based on mere clientelism, which is part of the relationships based on trade of support. The personal dimension of the patron-client or leader-follower relationship implies an ability to read into the political leader's attitudes and moods. This has nothing to do with some kind of vested interest, as one would measure the Head of 
Department's mood at the office in the morning. The attitudes and the moods of the leader provide essential information for his followers to be able to make sense of his politics, even for those who have emigrated, because understanding the leader's mood enables them to belong to the group of followers. This skill, which fuels competition between followers, must be mastered I order to stay in the game. In this context, being close to the political leader is not only the privilege of specific groups of henchmen whose social status depends entirely on this special relationship. Rather, the leader defines a sphere of political relevance in which people experience an unstable relationship with the distant image that the leader represents. And this image mirrors another image, for Walid Junblat owes his existence to his father, Kamal Junblat, who died as a martyr.

\section{The Stability of a Lebanese Political Core}

It is worth now considering the special ties created by this unusual relationship between the leader and his followers. Any relationship creates expectations that can be considered to be the expressions of desires. As analysed by Joseph (2005), the expression of expectations is highly valorised in Lebanon. Along with the permanent negotiation of all people's ability to enter the general competition, these expectations and the codified expressions of desire are foundational of the political order. There is something codified in the relationship that allows the expression of familiarity. The ritualised practices that the political order entails are the breeding ground of partisan societies. These "political poles" do not simply centralise a community-based power or exercise their dominance over society. It is as if they had the power to expand life and a world of possibilities.

This dimension is particularly visible in the tradition of the weekend visits to Mukhtara. These visits obviously make up the "poles". You do not have to have any request to make, or a project to propose, in order to visit the place; you are allowed to go simply to see friends, to learn the latest news, to be at the Palace. The public hearings enable people to make a place for Walid Junblat in their life on a weekly basis, thus organising their life within a space whose limits are defined by the regional villages, from which nobody regularly goes to Mukhtara. A convenient image is to picture it as a spider's web with the palace at the centre connecting surrounding places, or a lighthouse whose light circle encapsulates a world progressively fading in the penumbra. The political space in which these relationships are practiced is not necessarily the territory marked by civil war checkpoints. While the Shuf is an historical and an administrative area, defined as such under the organized Civil Administration of the Mountain under the 
government of the PSP militia (1983-1990), the relational space emerges from the noria of people visiting Mukhtara.

In return, Walid Junblat, and quite recently his son Taymur, pay visits each month to grieving families. During these condolence visits, people traditionally wish the relatives of the deceased an extra piece of life ${ }^{5}$ released by the latter, according to the famous Lebanese expression: "al-'awad bi-salâmtak" (may the rest of his/her life increase your health). However, when the lord from Mukhtara offers his condolences, the relatives of the deceased in turn use the same famous expression to wish him and his health the lifespan left by the deceased. As funerals are concerned, the lord belongs to the circle of relatives. Somehow, people return to him the wish he was offering them, as if he was the one entitled to play the part of the head of the household for the dead family member. This ritual highlights the central place of the leader within family life.

Walid Junblat formalises this interdependence by keeping his own relatives away from the public gaze, except his wife and children. The only portraits he exhibits in his lounge are those of his father Kamal, of his grand-mother Sitt Nazira, and of the drivers who died in the attacks targeting him which killed his father. All of these portraits reflect his political lineage and represent the martyrs who make up the family's political legitimacy. Mukhtara is exhibited as the product of a line of leaders, with no collateral members who could constitute a ruling family. The reference to his own family, or what could be called the Junblat clan, is entirely wiped out from public life as well as from his speeches, so much so that it is almost impossible to get information concerning Walid Junblat's relatives (uncles, aunts, cousins) when questioning people in the Shuf. This is surprising given that they are usually keen on talking about the lords from Mukhtara. It could be that they just do not know these details. More certainly, it is only the public absence of Junblat's extended family that permits him to be granted a place as a putative member in the families that support his policy.

Nevertheless, the symbol of the extra piece of life delivered by death is magnified in the way that martyrs are considered. The martyr has a central place in all Lebanese communities, but their modalities and their implications differ. Being a martyr is to have a Lebanese destiny, according to Antoine Messara (1988). This is why martyrdom can be considered to be a strong symbol of the Lebanese political sphere, which can be fully understood only through comparative studies of the nation's regional differences. Martyrdom can be analysed as a specific process of violence: martyrdom forces violence out of the routinized logics of confrontation, only to be foundational to the social or

$5 \quad$ This conception stands on the idea that each human being is entitled 100 years of life. Birthday greetings built on this idea wishing with every passing year that one "reach the 100" ('uqbal el-miyye, in sha' Allah). Consequently, each person dying before reaching 100 years leave behind an extra period of life that should benefit someone. 
political order. In the Druze community, martyrs are not considered to be individual figures. This distinguishes them from the Shi'i communities, and also from the Sunni communities in the north of Lebanon (Volk 2009). Instead, the Druze all vanish behind Kamal Junblat's paradigmatic figure, which represents the martyr par excellence. Few banners or portraits of the lord in charge can be found in the Shuf, which is Walid Junblat's realm. As such, the Shuf stands in sharp contrast to other Lebanese regions, in which posters of ruling leaders are displayed.

The main, if not the only, reference to politics is made through the evocation of Kamal Junblat, who is materialised most of the time by plaques and cenotaphs produced in his honour. These can be seen in village squares. On September 6, the day of his birth, small candles placed by PSP youth along all the roads of the region illuminate the area. The evocation of Kamal's martyrdom has gone beyond the level of war rhetoric, inspiring nowadays an interpretation of sacrifice, which transforms the leader assassinated in 1977 into an almost Christlike figure. As people saying goes: 'Kamal bey, as other Junblats before him, has shed his blood on Shuf lands, and it's thanks to this sacrifice that our people are still alive.'

Violent death seems to be systematically associated to Kamal Junblat. When two young men from Baaqline, who were members of the PSP youth, died in a car crash, their friends had decided to pay them a tribute by creating a memorial where Kamal Junblat's books would be sold. This way of dealing with the dead associating them with the most famous communal figure to ensure the sustainability of their personal memory - evokes a disposition I have already analysed (Rivoal 2000: 378). Coherent with their belief in reincarnation and the notion of the body as a mere piece of cloth for the soul, the Druze forbid the individual marking of tombs. However, a way to circumvent anonymity is to significantly contribute to the renovation of a shrine in order to be associated with the holy figure, and to eventually be buried next to it with his name marked on the grave. Kamal Junblat was buried in his castle of Mukhtara, in a shrine-like tomb. Only the two bodyguards killed in the attack are buried next to him. The life-size monument dedicated to the civil war martyrs is associated with combatants in the 1860 war. It stands as an encompassing, yet anonymous, symbol of Druze martyrs. This monument was built in Duwwar (at the crossroad between Baaqline, Beiteddin, and Baqaata) in the centre of a territory that is strongly marked by Kamal Junblat's memory. The religious dimension through which the martyr's figure is reinterpreted enables Walid Junblat to maintain his own identity as "Walid", being the son of, and grandson of his predecessors all the while being the actual political reference for the people. This is possible because Mukhtara is a persistent actualisation of a lineage that keeps writing the regional history. 
This lineage does more than capture history by dominating it. The Junblat leadership is not limited to Walid Junblat, and it existed long before Kamal, whose death had been preceded by other violent deaths (that of his father, and also of Bashir Junblat, who was killed by Bashir Shihab in the eighteenth century). In this context, the image of the leader has two facets, and the reference to the martyr represents more than a reference to his memory. For instance, when Ibtissam practices yoga, she makes Kamal present: one has to be connected to the dead to ensure a better life, whether through meditation or another form of remembrance. This is precisely what gives historical depth to the political lineage, as well as legitimacy as far as its leadership is concerned.

\section{Conclusion}

The anthropological perspective that I have developed in this article rests on the idea that Lebanon can only be understood on the basis of partial totalities, which are reciprocally defined in a political game of alliance and confrontation. They are localized political expressions that seem never-ending and must be described in their complexity. We cannot exhaust our understanding of politics in Lebanon by describing power as principally manifested in a confessional system and patronage relationships. Picturing political relationships as sheer domination exerted by external or distant politicians is a misconception. Leaders do not force their views on a society that, in Western eyes, is expected to slowly move toward developing a civil society to escape so-called old-fashioned forms of domination. "Civil society" cannot escape the political sphere. However, whether it even exists within this sphere is questionable.

The art of politics goes far beyond the control of asymmetry in the distribution of economic and human resources. Patron-client relationships do not function as a duality in which the terms of engagement are defined in a reciprocal and univocal way. Their asymmetry works, rather, in the manner of a polarization. This engenders questions of what their zones of influence are, and what the mechanisms of their operation are. In other words, there is much more than power in patronage relationships. There is a multiplicity of definitions of "in relation to" that can never be presupposed because these relations depend on local context and are constantly modified by the game itself. 


\section{References}

Dib K. (2004), Warlords and Merchants. The Lebanese Business and Political Establishment (Reading: Ithaca Press).

Gubster P. (1973), 'The Zu'amâ of Zahlah: The Current Situation in a Lebanese Town', The Middle East Journal, 27, no. 2: 173-189.

Gilsenan M. (1977), 'Against Patron-Client Relations', in Patrons and Clients in Mediterranean Societies, (ed.) Gellner E. and J. Waterbury (London: Duckworth), 167-183.

Gilsenan M. (1986), 'Domination as a Social Practice. Patrimonialism in North Lebanon: Arbitrary Power, Desecration and the Aesthetics of Violence', Critique of Anthropology, 6, no. 1: 17-37.

Gilsenan M. (1989), 'Words of Honour' in Social Anthropology and the Politics of Language, (ed.) Grillo R. (London and New York: Routledge), 193-221.

Gilsenan M. (1996), Lords of the Lebanese Marches. Violence and Narrative in an Arab society (London and New York: I.B. Tauris).

Hage Gh. (1997), 'At Home in the Entrails of the West. Multiculturalism, "Ethnic Food" and Migrant Home-building' in Home/World: Community, Identity and Marginality in Sydney's West, (ed.) H. Grace, Gh. Hage, L. Johnson, J. Langsworth and M. Symonds (Annandale: Pluto Press), 99-153.

Harik J. (1993), 'Change and Continuity Among Lebanese Druze Community: The Civil Administration of the Mountain, 1983-90', Middle Eastern Studies, 29, no. 3: 377398.

Hichi S. H. (1973-1974), La famille des Djoumblatt du VII siècle à nos jours (Beyrouth: n.s).

Hudson M. (1968), The Precarious Republic. Political modernization in Lebanon (New York: Random House).

Johnson M. (2001), All Honorable Men. The Social Origin of War in Lebanon (London and New York: I.B. Tauris-Center for Lebanese Studies).

Joseph S. (1993), 'Connectivity and Patriarchy Among Urban Working-Class Arab Families in Lebanon', Ethos, 21, no. 4: 452-484.

Joseph S. (2005), 'Learning Desire. Relational Pedagogies and the Desiring Female Subject in Lebanon', Journal of Middle East Women's Studies, 1, no. 1: 79-109.

Karam K. (2006), Le Mouvement civil au Liban. Revendications, protestations et mobilisations associatives dans l'après-guerre (Beirut : Karthala-IREMAM).

Khalaf S. (2001), Cultural Resistance. Global and Local Encounters in the Middle East (London: Saqi books).

Khuri F. (2004), Being a Druze (London: The Druze Heritage Foundation).

Kingston P. (2001), 'Patrons, Clients and Civil Society: A Case Study of Environmental Politics in Postwar Lebanon', Arab Studies Quarterly, 23, no. 1: 55-72.

Messara A., (1988), 'The Challenge of coexistence', Prospects for Lebanon Paper (Center for Lebanese Studies [October]). 
Picard É. (1994), 'Les habits neufs du communautarisme libanais', Culture et conflits, no. $15-16: 49-70$.

Rivoal I. (2000), Les Maîtres du secret. Ordre mondain et ordre religieux dans la communauté druze israélienne (Paris : Editions de l'EHESS).

Rivoal I. (2001), 'Baaqline, de l'Administration civile de la Montagne à la renaissance municipale. Réflexion sur le pouvoir local au Liban' in Pouvoirs locaux et municipalités au Liban, (ed.) Favier A. (Beyrouth: Les Cahiers du CERMOC, $n^{\circ} 24$ ), 319-338.

Volk L. (2009), 'Martyrs at the Margins: The Politics of Neglect in Lebanon's Borderlands', Middle Eastern Studies, 45, no. 2: 263-282. 